\title{
The Pacific Northwest Renaissance Society
}

\author{
PAUL BUDRA \\ Simon Fraser University \\ JEAN MACINTYRE \\ University of Alberta
}

The Pacific Northwest Renaissance Society (PNRS) is one of the oldest conIt is, perhaps, unique in having a binational agenda: since its early days, it has brought together scholars from both sides of the Canadian/American border in the northwest of the continent. In the 1970s, cross-border communication became part of the society's written constitution, administrative structures, and conference practice. Our essay will attempt to outline the history of the society, from its first meetings almost sixty years ago, and address some of the issues that confront the PNRS and other small Renaissance societies in the age of digital humanities. ${ }^{1}$ This history is based on documentation that is spotty and human memories that are fading. Few of the society's formal minutes survive from before the 1980s, so the motivations and even the names of key players behind certain early decisions and events are not always clear.

The Pacific Northwest Renaissance Conference (PNRC), as it was originally known, began almost simultaneously with the Renaissance Society of America (RSA). Its first meeting was organized in 1956 by Quirinus Breen (History) of the University of Oregon, Paul Pascal (Classics) of the University of Washington, and G. P. V. Akrigg of the University of British Columbia. Its modest beginnings are recorded in the program (the earliest to survive) for its 26-27 April 1957 meeting at the University of Washington. This was a joint meeting with two other regional societies-the Northwestern Chapter of the American Musicological Society (AMS) and the Classical Association of the Pacific Coast, Northern Section-and consisted of seventeen papers and two plenary lectures: "Theory and Creation in the Italian Renaissance" by Oscar

1. This essay updates and extends material that Jean MacIntyre originally provided for the society's website: http://www.pnrs.org/about.html.

Renaissance and Reformation / Renaissance et Réforme 37.3, Summer / été 2014 
Budel (UBC) of the PNRC and "Humanism in the Music of the Renaissance, North and South" by Edward Lowinsky of the Musicological Society. Other speakers included A. C. Hamilton, Jean Alexander, and Akrigg, whose paper on the English court seems a foretaste of his The Jacobean Pageant (1962).

In April 1958, the PNRC again met jointly with the AMS and the Classical Association at the University of British Columbia. The program looks much smaller than that of the year before, with only seven PNRC papers and seven AMS (two late addenda to the program); Classical Association programs, however, were being distributed on-site, so the program was probably about the same length as that of 1957. The 1959 meeting was the PNRC's first solo flight, a one-day gathering at Gonzaga University in Spokane, during which nine papers were presented. Among the presenters were Breen, Pascal, and Fred and Katherine Stockholder.

The meeting of 1960 (May 20-21) at the University of Oregon marked an advance in the PNRC fortunes. Whereas the previous programs had come out of mimeograph machines, this one was printed, and for the first time a distinguished speaker from outside the region was to have been featured. Paul Oskar Kristeller was to have spoken both on the "Aims and Projects of the Renaissance Society of America" and on "The Platonic Academy of Florence." A last-minute change was announced in the purple ink of hectograph: "The Local Committee regrets to report that an automobile accident has prevented Professor Kristeller's attendance." The printed program in the PNRC archives shows rapid rearrangements of the papers and the substitution of a paper on "Milton and Perspectivism" by Kester Svendsen for Kristeller's on the Platonic Academy.

In 1961 the meeting returned to the University of Washington and to a joint conference with the AMS, whose program dominated the meeting. Frederick Waller of Portland State College presented a paper, and the next year organized the conference. Charles LeGuin chaired a session notable for three distinguished historians, Breen, Samuel Kisner, and F. J. Levy. The first contingent from the Canadian prairies came to the 1963 meeting in March at Western Washington State College in Bellingham, and in 1964 the attraction of Eugene brought more prairie Canadians fleeing winter. Hilton Landry and Homer Swander came from California and Lawrence Rice from Idaho, and the plenary speaker was A. L. Rowse. This meeting is also the first to record an administrative structure, with Kester Svendsen stepping down as president (the 
office now called conference chair) and an unnamed "president-elect" designated to preside at the conference dinner. Unfortunately, whatever constitution may have articulated that fledgling executive structure no longer exists.

The 1965 meeting moved inland to Central Washington State College in Ellensburg, home campus of the PNRC secretary Larry L. Lawrence. This meeting attracted a number of inland speakers-Baird Whitlock of Wyoming, John Sisk of Gonzaga, Pat Ryan of Eastern Montana, Murray Markland of Washington State, and William Hunter of Idaho-but the location worked against attendance from coastal areas and, for the first time, no Canadians appeared on the program. The first meeting at the University of Victoria remedied this lack in 1966; although the number of papers was small the attendance was not. The most memorable event of this conference was the riveting performance of Middleton's The Changeling. This was the first time a theatrical performance had been part of the program of the PNRC but, as we shall see, it would become a distinguishing feature of this conference. When theatrical performances have not been possible, conference organizers have staged musical performances. At the meeting in 2011 in Spokane, Washington, conference attendees were invited to mount a group reading of Francis Beaumont's Knight of the Burning Pestle.

The 1967 meeting at Washington State University proved that a wintry inland location (March 16-17) distant from an airport hub would restrict attendance to locals and those willing and able to drive. Despite the attraction of plenary lectures by Lynn White, "The Virtuousness of Technology in the Fifteenth Century," and by Linda Van Norden, “'De Fluctibus: Dove or Raven?" and a return to a joint session with the AMS, attendance was thin; besides the two PNRC plenary talks and the musical attractions, there were only seven PNRC papers on the program. That remoteness from an airport, rather than winter conditions, was the main cause was proved by the very large attendance at the University of Alberta's debut as PNRC conference host in 1968; for the first time, a speaker came from the University of Alaska. This conference followed the example of Victoria's presentation of a full-length Renaissance play with Bernard Engel's production of Jonson's Volpone. In 1969 Lewis and Clark College extended the tradition with a memorable concert performance of Middleton's A Trick to Catch the Old One.

The 1970s opened with a new conference host, Seattle University, and an opening address by Virgil Whitaker. Despite the meeting's US location, 
Canadian speakers outnumbered American, and the same thing happened as Portland State (now a university) hosted the meeting for the second time in 1971. This year it was decided that meetings of the PNRC should alternate between a US and a Canadian institution; the binational nature of the conference was recognized in continuing practice. Accordingly, early in March 1972 members braved the prairie winter for a second time for the first meeting at the University of Calgary. An interesting feature of this meeting, like that at Seattle University two years before, was the appearance on the program of specialists in American literature from the University of Alberta venturing with some success into Renaissance studies. The meeting in 1973 (at the University of Oregon) introduced concurrent instead of sequential sessions and for the first time imposed the necessity of choice upon the members. This meeting continued the dramatic tradition with a performance of Robert Greene's Friar Bacon and Friar Bungay.

In 1974 members yet again braved winter (in an extreme form indeed) for the March 15-16 meeting at the University of Regina, Saskatchewan. Despite the cold (severe enough to generate ice fog and sun dogs in the early morning) the meeting was well attended, and well compensated not only by plenary addresses from William Blissett of the University of Toronto and Austin Woodrych of the University of Lancaster, but especially by an extemporaneous address: "Shakespeare's Dramatic Challenge," from G. Wilson Knight-which Geoffrey Aggeler managed to record, at the last-minute starting up a tape recorder (a recording that is still alleged to be in his possession). The 1975 return to a more salubrious climate at the southern edge of the conference region in Ashland, Oregon, proved insufficient attraction; again the difficulty of getting to a site without an airport limited attendance and led to a resolution not to hold meetings in such locations again.

Despite the intended return to the University of British Columbia, handy to the Vancouver International Airport, the PNRC meeting was cancelled in 1976 for the only time in its history. This was caused by two unforeseen disasters: the illness of Secretary Reg Ingram might have been coped with, but, as he wrote to the members, the long national postal strike in Canada prevented useful organization of a conference in sending out calls for papers and the receiving of them. The strike ended a couple of weeks before Christmas, but the rush of seasonal mail hampered the resumption of normal service. Indeed, the last three letters enquiring about the PNRC 1976 meeting were dated December 14, 
December 15, and January 9; the December letters came together on January 16 , the third letter arrived January 20. Ingram promised that despite this cancellation, "every effort will be bent to make the 1977 meeting [...] as fine an affair as possible to offset this year's interruption." This proved true. The conference featured a distinguished set of papers, a concert including original music to Renaissance texts, and a postprandial performance of Thomas Middleton's The Revenger's Tragedy (the play was, in those days, attributed to Cyril Tourneur).

Throughout the years just chronicled, the size of the program, after a modest growth in the 1960s, remained about the same: a dozen or so papers; one, two, or three plenary lectures. The conference saw a sudden expansion when it met for the third time at the University of Washington in 1978. After Akrigg's plenary lecture, "A Renaissance Monarch: James VI and I" and the single 60-minute session that followed, the rest of the conference divided into paired 90-minute sessions. A second plenary address was delivered by C. L. Barber at the unprecedented hour of 8:30 a.m. Saturday, and for the first time sessions continued into Saturday afternoon for a total of twenty-six papers. The next year at the University of Victoria, Stephen Orgel, then of Johns Hopkins, gave his first lecture at the PNRC, and the number of papers went down to eighteen. This conference, like many in the 1970s, brought an increasing number of speakers from well outside the region. Garry Waller of Dalhousie was succeeded in this year by David Galloway of New Brunswick and the Records of Early English Drama project.

The 1980s began with a meeting jointly held by Pacific Lutheran University and the University of Puget Sound in Tacoma, Washington, which again saw the number of papers climb into the twenties and the conference length extend from one-and-a-half days to almost three. This meeting was notable in several respects: the amount of publicity it received in the Tacoma newspapers; the receipt of an official certificate of welcome from the mayor (the only time to date it has been so distinguished); the innovation of a seminar on Shakespeare's Coriolanus, led by Chester Garrison of Oregon State University. Finally, a morning-long panel discussion on the "Future Directions of the Pacific Northwest Renaissance Conference"-by D. E. Van Tassel, who had organized the conference, Ronald Meldrum, the conference secretary, and S. K. Heninger-was followed by the annual business meeting and a consideration of the panel's questions, all of which led to the writing of a constitution and by-laws that provided for a president, a vice-president who automatically 
succeeded, a continuing secretary, and an elected board. The first officers under the new dispensation were D. E. Van Tassel, president, and R. F. Jones, secretary, both of Pacific Lutheran University. This meeting also gave the PNRC a recurrent image: that of the Inigo Jones's design for an anti-masque, Crier of Mousetraps.

Simon Fraser University hosted the PNRC in 1981. Owing to the lack of adequate accommodation near the Simon Fraser campus in Burnaby, sessions of the conference were held for the first time in a downtown location near the conference hotel, though a bus took the members to the university for the Saturday morning sessions. This meeting was smaller than the one in Tacoma, though it attracted presenters from as far away as Texas and New York. Portland State in 1982 revived the tradition of performing a Renaissance play with a production of Rafe Roister Doister. Because the Oregon Shakespeare Festival at Ashland was to produce Shakespeare's Henry $V$ that season, among the sessions devoted to it were a symposium on the play, a lecture "From Text to Stage: Problems of Production," by its director Pat Patton, with a panel discussion and questions afterwards, and two papers about the play. (The performance that summer showed that the director had not listened to audience critiques of his addition to the script of scenes from Henry IV Part 2.) There were also papers dealing with Renaissance political ideas.

In 1983 the conference returned to the University of Alberta. Thanks to a generous grant from the president of the university, Dr. Meyer Horowitz, and assistance from Dean of Arts Terry White, this conference had "lavish means" for the production of John Redford's St. Paul's School play Wit and Science-directed by Patricia Demers, with a cast that included students, staff, and professional actors, and original music by Malcolm Forsyth-during the conference banquet. Musicologists were in attendance, though not as a formal society, and "A Musical Conclusion, Parody Technique: 'Theme and Variations' of Renaissance Music" by Leonard Ratzlaff and the University Madrigal Singers wound up the conference. At this meeting it was decided that the PNRC should affiliate with the Canadian Society for Renaissance Studies / Société canadienne détudes de la Renaissance (CSRS/SCÉR) and give financial support to the journal Renaissance and Reformation / Renaissance et Réforme, support which has continued to this day. The 1984 conference, jointly hosted by Seattle Pacific University and the University of Washington, introduced a new element: "Seminars on Special Topics" on the Saturday afternoon. The 1986 meeting 
was to be held at Whitworth College in Spokane, but the departure of key staff members at this small institution threatened another cancellation. To prevent this, the president organized an ad hoc meeting in February, much earlier than usual, at the Portland Hilton. Despite the "emergency" nature of the organization, this conference attracted over twenty-five presenters and a fair number of people from the region to listen to them.

The University of Oregon's third meeting of the PNRC in 1988 almost doubled the size of the largest meeting to date, with nearly fifty papers, two plenary lectures by Stephen Orgel (Stanford) and Arthur Kinney (University of Massachusetts), and an extremely lively not to say contentious panel discussion on New Historicism by David Harris Sacks, Don Wayne, and William Kerrigan which opened the conference. (The historians left little but shreds and tatters of this newly-fashionable -ism). It also seems to have been the year in which an announcement of the next year's conference first appeared in the program. In 1990, the Seattle University program announced the sites and dates for the next two years. The 1990 conference saw the return of Pat Patton of the Oregon Shakespeare Festival to discuss "The Future of Shakespeare in Performance at Ashland," but, perhaps owing to the major effort of two years before, the program was not very extensive, although there were quite a few split sessions and many of the papers were of considerable distinction.

The conference returned to Vancouver and Simon Fraser University in 1991. The Shakespeare Association of America (SAA) held its conference in that city the same year, so the PNRC organizers scheduled their conference earlier in the week than normal. Instead of running on Friday and Saturday, it ran on Wednesday and Thursday. This allowed participants to also attend the SAA meeting, which was held at a hotel just up the street from Simon Fraser University's Harbour Centre where the PNRC was convening. The two PNRC plenaries were Alexander Leggatt (Toronto) and Stephen Greenblatt (Berkeley, now Harvard). Greenblatt, famous for Renaissance Self-Fashioning and as a founder of the New Historicism movement, attracted a large audience of nonconference attendees, the first time this had happened at the PNRC. His talk was based on the book he was writing at the time, Marvelous Possessions.

The University of Puget Sound meeting of 1992 initiated the arrival of many new members to the PNRC, including one undergraduate and several graduate students, in an especially varied program that included a "work in progress" session on Renaissance women, following a plenary lecture by Hilda 
Smith (Cincinnati) on "Women's Citizenship in Early Modern England." This was the first showing of women's studies at a PNRC conference, and it generated lively debate. The second plenary speaker was the art historian Michael Baxendall of the Warburg Institute and the University of California. The following year the University of British Columbia's wonderfully interdisciplinary conference committee set a theme for the conference, "The Reader, the Subject, and the Self in Early Modern Europe," and for the most part received cooperation from those who submitted papers for an unusually varied group of sessions-more than forty papers, including the innovation of the papers in one session being delivered in Italian, a precedent that was to be followed two years later. The conference committee designed an exceptionally handsome program containing many Renaissance images printed in red on white, arguably the most beautiful yet created for a PNRC meeting. The increase in the number of papers made multiple concurrent sessions a regular feature of the PNRC. In 1994 there were only thirty-three papers (one jointly written and delivered) but three sessions at a time ran nonetheless.

The 1995 meeting saw another innovation. Its host, the University of Calgary, held joint sponsorship not only with another Calgary institution, Mount Royal College, but with the rival University of Alberta; moreover, the meeting took place not on the host campus or even in the host city, but in Banff. The three dozen papers were, as usual, distinguished by variety: a session of papers delivered in Italian; full sessions on Italian art and Spanish literature of the Renaissance; and for the first time, a presenter from a German university, Eckhard Auberlen of the University of Tübingen. Probably the most memorable feature of this gathering was the lecture-recital given by the lutenist Victor Coelho of the University of Calgary. The meeting, held in early April, was lucky in unseasonably warm weather that allowed some participants to go swimming in the Upper Hot Springs pool while those without bathing suits looked down in envy.

Seattle University again was host for the 1996 meeting; and here, for reasons involving its legal incorporation as a society eligible for charitable status, the PNRC was renamed the Pacific Northwest Renaissance Society. Unfortunately it proved impossible to secure charitable status, largely due to the cross-border structure of the organization, and the word "society" has proved to be something of a misnomer as the only activity of the group has been its annual conference. But the move from a "conference" to a "society" 
did help clarify the group's status in preparation for hosting the RSA in 1997. Although the PNRC has been an affiliate of the RSA ab urbe condita, there is little evidence of contact between the national society and this regional conference at least in its early days. Kristeller's intended visit in 1960 was prevented by circumstances beyond his control. The next document relating to the affiliation is a letter of December 1970 from the RSA executive director that asks the then secretary, Robert I. Williams of Portland State, to be the delegate from the PNRC at the national Council's meeting in New York at the end of January 1971. Apparently that did not happen because there was no financial aid for anyone to cross the continent to attend. In September 1980 President Van Tassel invited the RSA "officers to consider meeting in conjunction with the PNRC in the near future," but there is no record of what answer he received. When as PNRC president Jean McIntyre attended the 1984 RSA convention in Chicago, she was one of only three persons at either the meeting or the Council from west of the Mississippi. Well in advance of one PNRC meeting, the then PNRC president, James Black of Calgary, did invite the RSA to hold its annual meeting in Banff concurrently with the PNRC. He received from an RSA officer what appeared a favourable enough reply to let him approach the Banff Springs Hotel about a meeting site, but the encouraging letter proved chimerical. When PNRC president Paul Budra made the journey to New York in 1995 to issue another invitation to the RSA, this was only the second time a delegate from this region is recorded as attending an RSA Council meeting.

The 1995 meeting led to the hosting of the RSA in Vancouver, Canada in 1997 by the PNRS, through Simon Fraser University. This conference was a watershed for the PNRS in a number of ways. It was, by far, the largest conference ever held by the PNRS - with over one hundred sessions. The plenary speakers were Annabel Patterson (Yale), who spoke on anxiety and portraiture, and Paul Grendler (Toronto), who gave an amusing lecture on the honorary doctorate Erasmus received from the University of Turin. The PNRS sponsored its own sessions and was able to bring in speakers from across Canada, thanks to a Social Sciences and Humanities Research Council grant. This PNRS/RSA meeting was extraordinary for another reason: it made money. The profit from the conference, some $\$ 20,000$, effectively increased the PNRS's financial holdings by a factor of ten. Finally, this was the first time the PNRS took advantage of the rules that allow affiliated organizations to host sessions at the RSA. It would not be the last. The PNRS has gone on to host sessions at the RSA's conference in 
Florence in 2000, Los Angeles in 2009, the 2010 meeting in Venice, and others. In 2006, the PNRS held its conference in conjunction with the RSA's annual meeting in San Francisco. Since the 1997 conference, the relationship between the RSA and PNRS has been much closer.

With a financial safety net (from 1997), the PNRS finished the twentieth century with a number of very strong conferences. The 1998 conference was held at Western Washington University and featured the plenary speakers Huston Diehl and Susan Karant-Nunn. The following year it was hosted by the University of Saskatchewan in Saskatoon, with historian Daniel Woolf and Michael Best as the plenaries. (Woolf holds a record for the most number of times as PNRS speaker.) One of the highlights of that conference was a classical guitar recital by Peter Stoicheff.

The first decade of the twenty-first century saw the PNRS holding its conference for the most part in Washington State and British Columbia, but there were a few exceptions: in 2002 it was held at Marlborough School in southern California, stretching the definition of "Pacific Northwest" to an extreme. In 2005, the conference returned to Banff, Alberta, and in 2009 it met in Boise, Montana, under the sponsorship of Gonzaga University. One of the highlights of that conference was a reception held in the university's rare book library. On display were many early modern books, including a copy of Thomas North's translation of Plutarch's Lives, an important source for Shakespeare's Roman plays.

The PNRS, then, has had a long and varied history. Moving forward, the society faces a number of challenges that may be symptomatic of those confronting other regional academic societies. First, the PNRS started as a multi-disciplinary conference with an emphasis on musicology and history and has attempted to remain so by actively encouraging participation from a variety of academic disciplines and by bringing in plenary speakers with varied specialities. Despite these attempts, in the past few years the conference has become increasingly dominated by scholars and graduate students of English literature. Of late there have been entire PNRS programs with little else. The reasons for this are many: early modern English literature contains Shakespeare and a variety of other world authors that attract disproportionate attention. Some other disciplines, such as French, have seen precipitous declines in their Renaissance offerings (as long ago as 1999 there was a colloquium at Simon Fraser University on the decline of French Renaissance studies). Art historians, musicologists, and historians all have their own local and national conferences. 
Second, there are difficulties around membership. Except for a small group of regulars, the PNRS tends to attract scholars only for specific iterations of the conference. They pay their dues just for that year. This makes it difficult to budget and plan for the next annual conference. There are many colleges and universities in the PNRS's geographic region (especially in the US) that have never participated in the conference. This may be indicative of larger trends in the academy and the impact of digital humanities on the scholarly community. As we all know, the internet has profoundly changed scholarship, perhaps especially early modern scholarship. Early English Books Online has given scholars instant access to texts once only available by visiting distant libraries or manhandling reels of microfilm. Digital archives, editions, and maps have freed scholars from the necessity of expensive travel, but the internet has also had an impact on the scholarly collegiality of the conference. Before the advent of email and the web, scholars around the world had limited, or very slow, possibilities for communication with other scholars. They had to come together to exchange ideas. But the web has made it possible and easy for scholars to form virtual communities of interest with the click of a button. No longer does a professor have to fly around the world (like David Lodge's Professor Morris Zapp) to engage with other scholars, share knowledge, and trade papers. Small regional conferences have become less essential to maintaining the scholarly community while large national conferences continue to flourish because of their demographic weight and putative prestige. Indeed, if it were not for a small coterie of regular attendees who have rotated through the PNRS's executive positions and who promote the annual meeting in their own institutions, the society might well wither away.

Fortunately graduate students are quick to attend local conferences, and some of the PNRS's recent meetings have seen almost as many students as established scholars in attendance. This is not in and of itself a bad thing. The PNRS has always been welcoming to graduate students and, on occasion, undergraduates. But if the trend continues, the society may have to re-assess the mandate of the annual conference. If it is to be dominated by graduate students, perhaps the conference could be viewed as a training ground for aspiring scholars and sessions could be held on topics of interest to students hoping to become professional scholars.

Partly in response to concerns about attendance numbers, four years ago the PNRS began an experiment with its schedule. Traditionally the conference 
had been held in the spring, running from a Thursday night through a Saturday afternoon. The problem with this time of year was the possibility of conflict with the RSA and SAA, both of which hold their annual conferences in the spring. In 1991, 1997, and 2006 the PNRS worked around this by holding the conference in conjunction with the larger society, but most years the first job of the society executive was to research the dates of the RSA and SAA meetings and then plan a PNRS meeting that would avoid both. The executive decided to move the conference to the fall, starting with the 2010 Victoria meeting, to avoid this recurring conflict.

The PNRS has some added logistical challenges because of its mandate to balance its Canadian and American constituencies. The society's bylaws state that the nationality of the succeeding presidents will alternate between American and Canadian. Since the early 1970s the annual meeting has rotated between an American and Canadian venue. Officially, the geographic region of the society is Alaska, Idaho, Montana, Oregon, and Washington and the provinces of Alberta, British Columbia, and Saskatchewan-although conferences have been held in California. The reasons for this are historic: when the PNRC began, the Pacific Northwest was remote and inaccessible to most of North America. This remoteness, along with the easy communication between British Columbia and the American states to the south, meant that a cross-border north-south association was actually more convenient for local scholars. The early decades of the PNRC promoted much interaction between scholars in the Western states and provinces. As air travel has grown cheaper and more convenient, the isolation of the region from scholars from east of the Cascades and the Rockies has almost disappeared, and it is usual to find at least one or two presenters from as far east as Halifax and Boston on every PNRC program. The disadvantage of this is, as mentioned, that local scholars may pass on the PNRS meeting to attend a national conference in the East.

Finally, while the PNRS has a long relationship with the RSA, it is also (as noted above) an affiliate of the CSRS/SCÉR, a national organization that promotes multi-disciplinary scholarship in both of Canada's official languages; however, the relationship between the two societies has not been especially close. There may be two reasons for this. First, the CSRS/SCÉR holds its annual meeting at the Congress of the Humanities and Social Sciences, a vast gathering of Canadian learned societies that meets once a year in a different Canadian city. The emphasis here is on "Canadian." The American members of the PNRS 
are unlikely to attend the Congress or, therefore, the meeting of the CSRS/ SCÉR. Second, Western Canada is the least bilingual portion of the country, excluding the territories, and rates of French-speaking in the western American states are undoubtedly low; ${ }^{2}$ the CSRS/SCÉR's bilingual mandate may discourage some allophones from participating in its activities.

Nevertheless, the hope that the two societies may one day work more closely on scholarly projects is not unrealistic. Such a revived association with CSRS/SCÉR, along with even stronger ties to the RSA, could enrich the offerings of both-and give the PNRS more of the visibility it needs to thrive in the twenty-first century.

2. Statistics Canada, "Table 17: English-French bilingualism among Anglophones and allophones, (single mother tongue), Canada, provinces, territories and Canada less Quebec, 1996 to 2006," 1 April 2014, https://www12.statcan.gc.ca/census-recensement/2006/as-sa/97-555/table/t17-eng.cfm. See also "Table 6: Number of people and proportion of the population reporting French by selected language characteristic, Western provinces, 2006 and 2011," 8 September 2014, https://www12.statcan.gc.ca/ census-recensement/2011/as-sa/98-314-x/2011003/tbl/tbl3_1-6-eng.cfm. 


\section{Appendix of PNRS Presidents, 1983 to 2014}

$\begin{array}{ll}\text { 1983-1986 } & \text { Jean MacIntyre (University of Alberta) } \\ 1987-1989 & \text { Nathan Cogan (Portland State University) } \\ 1990-1992 & \text { James Black (University of Calgary) } \\ 1991-1995 & \text { Florence Sandler (University of Puget Sound) } \\ 1996-2001 & \text { Paul Budra (Simon Fraser University) } \\ 2002-2004 & \text { Marc Geisler (Western Washington University) } \\ 2005-2007 & \text { Patrick Finn (University of Calgary) } \\ 2008-2014 & \text { Gretchen Minton (Montana State University) }\end{array}$

